\title{
Development of Self-Exhibition Through Cognitive-Behavioral Counseling Models with Self-Management Strategies
}

\author{
Gede Nugraha Sudarsana \\ Guidance and Counseling Department \\ Universitas Pendidikan Ganesha \\ Singaraja, Indonesia \\ nugraha.sudarsana@undiksha.ac.idd
}

\author{
Ni Ketut Suarni \\ Guidance and Counseling Department \\ Universitas Pendidikan Ganesha \\ Singaraja, Indonesia \\ niketut.suarni@undiksha.ac.id
}

\author{
Ulan Sari \\ Guidance and Counseling Department \\ Universitas Pendidikan Ganesha \\ Singaraja, Indonesia \\ ulansari07@gmail.com
}

\begin{abstract}
This study aims to determine the effectiveness of cognitive-behavioral counseling models with selfmanagement strategies to develop a self-exhibition of state junior high-school students in Singaraja City. This type of research is a quasi-experimental research design with Nonequivalent Post-test Control Group Design that is research that uses intact groups. The study sample was 62 students who were determined using random sampling techniques by lottery. Data collection methods used were questionnaires and observations. Analysis of the data used in this study is the t-test. The analysis shows t-count (5.000) > t-table (2.00). The results showed that the cognitive-behavioral counseling model with an effective self-management strategy to develop a selfexhibition of state junior high-school students in Singaraja City. These results can be recommended to the teacher guidance and counseling to be an alternative assistance given to students to develop their potential and selfactualization such as self-exhibition to attract the attention of others.
\end{abstract}

Keywords: self-exhibition, cognitive-behavioral, self-management

\section{INTRODUCTION}

Teenagers are individuals who have a big influence on change, especially in the millennial era. They play an active role in the changes that exist and will affect their development as well. In the era of the Industrial Revolution 4.0, all fields of life will show change and one of these fields will be in the field of education. Nowadays, science is developing rapidly, and information can be accessed anywhere, anytime, and by anyone. This development will have an impact on the formation of adolescent behavior that specifically has a great curiosity. Every innovation always carries its own charm so that it cannot be denied that teenagers become one of the subjects that will determine the good or bad changes in themselves.

Education seems to provide an overview of the process of transfer of knowledge and information that can be done formally or informally. Education does not only focus on the cognitive aspects of individuals, but noncognitive aspects to balance it. These aspects have a great influence on the development of students both physically and psychologically. The non-cognitive aspect which is meant here is developing students' attitudes, behaviors, skills, and personalities. At school, students are not only given intelligence development, but characters are also formed, which can show the character of an intelligent and polite national child. Existing student behavior is developed in accordance with the values and norms prevailing in society as the aim that later students can complete their education and return for the community, they can be accepted by forming good character and able to behave according to existing rules. In addition, every development of his needs can be met.

Teenagers that are able to meet their psychological needs tend to show good social behavior. Because teenagers that are in a period of growth, and development tend to give more attention to their lives. Many spend time with their friends, and not infrequently they provide more protection to their friends.[1].

According to Edward, there are 15 types of human needs, including achievement, deference, order, exhibition, autonomy, affiliation, intraception, succorance, dominance, abasement, nurturance, change, endurance, heterosexuality, and aggression [2]. One of the needs that need to be developed now is the need for selfexhibition. Self-exhibition in question is the behavior of self-assertion in positive terms.

The era of the industrial revolution 4.0 provides broad opportunities for adolescents to be able to show themselves (self-exhibition) by developing the potential that exists within themselves. For example, many teenagers become Youtubers, Gamers, Celebrities, and so on. Through this, adolescents can build self-actualization and enhance the positive self-character.

Self-exhibition is one part of the construct of personality dynamics developed by Murray. According to Murray, personality must reflect behavioral elements that are permanent and repetitive and contain new and unique 
elements. Murray also put forward exhibition as one type of need, where the concept of need is the same as the concept of personality who is something abstract but related to physiological processes within the brain. The behavior of everyone is always influenced by personality dynamics [3]. So in this case more focused on meeting the needs in the form of behavior that is easily changed and observed.

Self-exhibition is shown by the behavior of saying something funny, logical and reasoning, telling stories and jokes, talking about his own experiences and personality [2]. Another understanding explains exhibition is one of the needs and efforts in individuals to show themselves to others [3] [4].

Individuals who have high exhibitions tend to show self-confidence, optimism, highlight achievements, want to be the center of attention, good sense of humor, and some people can catch the humor like seeking attention by "joking" in class [5] [6]. In addition to being the center of attention of others, exhibition is defined as the need to appear special [7].

Exhibition is a personality type that supports the ability to think critically by evaluating information and providing comments, questions or opinions submitted [8] Besides exhibition is a need to be admired, cared for and listened to [9][10].

So that self-exhibition is a behavior highlighting the potential and self-actualization so that it becomes the center of attention of others, which is done by saying and telling something funny, thinking about things that are logical and reasoning, telling personal experiences and successes themselves.

The development of self-exhibition on students is not only the responsibility to the students themselves, especially when viewed at the age of junior high-school students who are in their early teens. At this time, students still need guidance and support from the surrounding environment, both from parents, subject teachers, counseling teachers, friends, and others. The role of parents in helping children meet the needs of self-esteem namely as a model that can be observed by children directly, meeting the child's physiological needs, giving attention and affection to children in any situation, helping children control their social and emotional abilities. The development of self-exhibition is also influenced by students' cognitive and behavior, so there needs to be control of both. The worst thing that might arise if there is no control over the development of selfexhibition is the arrogant nature, tend to put down others, and the occurrence of moral degradation.

The provision of guidance and counseling services is one way that can be used to develop student selfexhibition. Like the research conducted by Ndagire in Urgana, which resulted that student behavior problems can be solved through guidance and counseling [11] Onyango added that the findings from the document analysis determined that guidance and counseling played a very good role in shaping the character of students [11] In this case, the counseling model that can be applied is the cognitive-behavioral counseling model.

Cognitive-behavioral counseling is a combination of two approaches in psychotherapy, namely cognitive therapy and behavior therapy. Cognitive counseling focuses on thoughts, assumptions and beliefs, and helps individuals to learn to recognize and change mistakes. Counseling is also not only related to the formation of positive thinking, but also related to happy thinking. Whereas behavioral counseling helps build relationships between problem situations and the habit of reacting to problems. Individuals learn to change behavior and calm the mind so that they feel better, think more clearly and help make the right decision [12].

Cognitive counseling is counseling that uses a structured, active, directive and short-term approach to appreciate personality barriers. This counseling is based on the theory that one's emotional state, feelings and actions are largely determined by how a person shapes his world. So the mindset formed by a person will affect the feelings and behavior that are shown. This cognitive approach invites individuals to be able to think realistically and in accordance with what is supposed to happen to eliminate or at least reduce the symptoms that are considered different [13].

Behavioral counseling has the basic assumption that every behavior can be learned, and old behavior can be replaced with new behavior. Humans can have the potential to behave well or badly, right or wrong. In addition, humans are seen as individuals who are able to reflex their own behavior, manage and can control their behavior and can learn new behaviors or can influence the behavior of others [14].

Cognitive-behavioral counseling is a fusion of approaches between cognitive and behavioral counseling in which one's mindset and way of thinking have a great influence on the formation of the behavior to be demonstrated. Where negative or irrational thinking helps shape bad behavior and behavior. However, if someone can form a positive and rational mindset, it is not impossible that the behavior exhibited will be the same. This shows that the formation of thought patterns, emotions, feelings, and beliefs greatly affect the development of behavior in a person.

Cognitive-behavioral counseling is counseling that focuses on restructuring or cognitive improvement that is distorted due to events that harm him both physically and psychologically and look more to the future than the past. Through thinking, humans decide on their actions, because thinking is a cognitive function of humans. Humans not only receive stimuli from what is seen through sensing, remembering events, and linking one event with another event with an associative legal basis, but process the information obtained through life experiences and cognitive functions. To support this, selfmanagement is also needed.

Self-management includes self-monitoring, positive reinforcement (self-reward), contracts or self-contracting, and mastery of stimulus (stimulus control) [13].

According to Yates "self-management is a strategy that encourages individuals to be able to direct their own behavior with responsibility for their actions to achieve self-improvement"'[15]. Self-management occurs because there is an attempt of the individual to motivate themselves, manage all the elements contained in him, trying to get what he wants to achieve and develop his 
personality in order to become better. When individuals can manage all the elements contained in themselves, which include: thoughts, feelings, and behavior then it can be said that the individual already can self-management.

The steps of the self-management strategy refer to the Yates Model self-management method, namely: 1) The stage of self-monitoring; 2) Stage of self-analysis; 3 ) Self-change stage; 4) Stage of self-maintenance [15].

Self-management strategy aims to help the counselee to be able to change negative behavior and develop positive behavior by managing themselves and the influence of rational thinking that is formed; record certain behaviors (thoughts, feelings, and actions) and their interactions with environmental events, restructure the environment as special cues, and present themselves and determine their own stimulus that follows the desired response.

\section{METHODOLOGY}

\section{a. Research Design}

This type of research is Quasi Experiment. The research design used is "Nonequivalent Posttest Only Control Group Design." Dantes stated that, in quasi research often used "intact groups," such as classes so that randomization cannot be done [16].

\section{b. Research Samples and Data Collection Methods}

The study sample was 62 students who were determined using random techniques by lottery. Data collection methods used in this study are self-exhibition and observation questionnaires.

\section{c. Experiment Procedure}

The procedures of this research are: 1) Preparation stage: making instruments, testing instruments, making observations, and preparing plans for implementing guidance and counseling services. 2) Implementation stage: a) Self-Monitoring, is a process of observing and recording everything about yourself and its interactions in the environment; b) Self-Analysis, is the ability to see, think, contemplate and assess yourself; c) Self-Change, is the ability to choose a solution determined in the previous stage: and d) Self-Maintenance, is an improvement and improvement of positive behavior that leads to the achievement of targeted goals. 3) Final Stage: conducting data analysis and drawing conclusions.

\section{d. Hypothesis testing}

Hypothesis testing is done using t-test. The purpose of this data analysis is to determine the effectiveness of cognitive-behavioral counseling models with strategic self-management to develop student self-exhibition.

\section{RESULTS AND DISCUSSION}

Student self-exhibition data were obtained through distributing self-exhibition questionnaires that met valid and reliability requirements. The hypothesis formulation in this study is a cognitive-behavioral counseling model with effective self-management strategies to develop students' self-exhibition.

Based on the analysis of table 1 obtained a t-count of 5.000 with $\mathrm{df}=60$ and a significance level of $5 \%$ so that a $\mathrm{t}$-table of 2.0 was obtained. These results indicate the $\mathrm{t}$ count (5.000) > t-table (2.0). This proves that the cognitive-behavioral counseling model with self- management strategies is effective for developing student self-exhibition.

The results of testing the hypothesis are as follows:

TABLE 1

Independent Samples Test

\begin{tabular}{|c|c|c|c|c|c|c|c|c|c|}
\hline \multirow[t]{4}{*}{$\begin{array}{c}\text { Self- } \\
\text { exhibition } \\
- \\
\text { assumed }\end{array}$} & \multicolumn{2}{|c|}{$\begin{array}{c}\text { Levene's } \\
\text { Test for } \\
\text { Equality of } \\
\text { Variances }^{\mathrm{a}}\end{array}$} & \multicolumn{7}{|c|}{ t-test for Equality of Means } \\
\hline & \multirow[t]{2}{*}{$F$} & \multirow[t]{2}{*}{ Sig. } & \multirow[t]{2}{*}{$t$} & \multirow[t]{2}{*}{$d f$} & \multirow[t]{2}{*}{ Sig. } & \multirow[t]{2}{*}{$\begin{array}{c}\text { Mean } \\
\text { Difference }\end{array}$} & \multirow[t]{2}{*}{$\begin{array}{l}\text { Std. Error } \\
\text { Difference }\end{array}$} & \multicolumn{2}{|c|}{$\begin{array}{c}95 \% \\
\text { Confidence } \\
\text { Interval of the } \\
\text { Difference }\end{array}$} \\
\hline & & & & & & & & Lower & Upper \\
\hline & .354 & .554 & 5.000 & 60 & .000 & 10.581 & 2.116 & 6.348 & 14.814 \\
\hline $\begin{array}{c}\text { not } \\
\text { assumed }\end{array}$ & & & 5.000 & 59.739 & .000 & 10.581 & 2.116 & 6.347 & 14.814 \\
\hline
\end{tabular}

${ }^{\text {aD }}$ ata Calculated Using SPSS 16.0 for Windows

Cognitive-Behavioral counseling model is an approach that views individuals have behaviors that are influenced by cognitive conditions (mind). The model emphasizes that changes in behavior can occur if an individual experience's changes in his cognitive. In addition, the counseling model is also juxtaposed with a self-management strategy as an amplifier for providing guidance and counseling services. This self-management helps students to be able to manage themselves well through modification of the functions of thinking, feeling, and acting. It also requires students to be able to analyze, decide, ask, act, and decide again.

Through this assistance, it appears that the development of behavior shown by students who are in early adolescence. Behavior that is shown after giving the cognitive-behavioral counseling model with selfmanagement strategies is a change in the way of thinking that is longer so that it affects behavior. The confidence shown by students becomes better. Students are not ashamed to tell their experiences in front of others, happy to get attention from others, often say funny things that cause other people's laughter, can think logically and reason. Students recognize the potential that exists within themselves and combines it with the ability to actualize themselves. This shows the proper development of selfexhibition has been obtained by students.

\section{CONCLUSION}

The results of this study have implications for teacher guidance and counseling that are as an innovation in providing guidance and counseling services that are not only beneficial for students' cognitive development but also student behavior. Train students to get to know themselves and manage themselves to meet their developmental needs.

\section{REFERENCES}

[1] S. Hunter and F. Sawyer, "Analyzing Teen Stress Symptoms," vol. 5, no. 5, pp. 774-785, 2019.

[2] N. K. Suarni, Metode Pengembangan Intelektual. Yogyakarta: Graha Ilmu, 2014.

[3] D. R. Afifah, "Profil Kecenderungan Kepribadian Mahasiswa Bimbingan dan Konseling Ditinjau Melalui EPPS (Edward Personal Preference Schedule) Studi pada 
Mahasiswa Bimbingan dan Konseling Angkatan 2012 IKIP PGRI Madiun," 2012.

[4] T. Amelia and R. D. Indriyanti, "Pengembangan Aplikasi Tes Kerpibadian Menggunakan Metode Edward's Personal Preference Schedule ( EPPS )," SNASTI, pp. 13, 2010.

[5] F. Novliadi, "Sense of Humor dan Kecemasan Menghadapi Ujian di Kalangan Mahasiswa," Sense Humor dan Kecemasan Menghadapi Ujian di Kalangan Mhs., vol. 42, no. 1, pp. 48-54, 2009.

[6] G. Larasati and A. R. D. Winarno, "Studi Deskriptif Identifikasi Kebutuhan Psikologis Anak Berbakat di Kelas Akselerasi," Psikodimensia, vol. 15, no. 1, pp. 58-87, 2016.

[7] L. Imelia and H. Kiswantomo, "Penyusunan Norma EPPS Berdasarkan Tingkat Pendidikan SMA , Perguruan Tinggi dan Rentang Usia Dewasa Awal," Humanitas (Monterey. N. L)., vol. 1, no. 1, pp. 25-36, 2017.

[8] G. S. Prihanti, "Hubungan Antara Kepribadian dengan Gaya Belajar Mahasiswa," J. Ilmu Kesehat. dan Kedokt. Kel., vol. 10, no. 1, pp. 74-83, 2014.

[9] J. M. R. Tuapattinaja and J. I. Saragih, "Gambaran Profil EPPS pada Mahasiswa USU EPPS Profile of USU Students," J. Pemikir. Penelit. Psikol., vol. 11, no. 7, pp. 37-46, 2016
[10] Y. Syafruddin, L. T. Hutabarat, S. D. Novalina, and Y. Sinaga, "rofil Kebutuhan Psikologis Taruna / I Akademi Teknik dan Keselamatan Penerbangan Medan," J. Psikol., vol. 2, no. 2, pp. 1-13, 2016.

[11] P. A. Onyango, P. J. Aloka, and P. Raburu, "Effectiveness of Guidance and Counseling in the Management of Student Behaviour in Public Secondary Schools in Kenya," Int. J. Appl. Psychol., vol. 8, no. 1, pp. 6-11, 2018.

[12] [John Winston Bush, "Cognitive Behavior Therapy: The Basics." 2003

[13] S. D. Gunarsa, "Konseling dan psikoterapi," Jakarta BPK Gunung Mulia, vol. 5, 1992.

[14] A. Steptoe, S. Kerry, E. Rink, and S. Hilton, "The Impact of Behavioral Counseling on Stage of Change in Fat Intake, Physical Activity, and Cigarette Smoking in Adults at Increased Risk of Coronary Heart Disease," Am. J. Public Health, vol. 91, no. 2, pp. 265-269, 2001.

[15] N. K. Suarni, "Meningkatkan motivasi berprestasi siswa Sekolah Menengah Umum di Bali dengan strategi pengelolaan diri model Yates: Studi kuasi eksperimentasl pada siswa kelas I SMU di Bali," Universitas Gadjah Mada, Yogyakarta, 2004

[16] N. Dantes, Metode Penelitian. Yogyakarta: ANDI, 2012. 